\title{
An object lesson in objection
}

\section{Lef Twithbuck}

There's always been conscientious objection in medicine. The inherent egotistical, "this is how it's done and what you'll do, if you want to get on" attitude that medicine breeds means it's often hidden. Or it's tough to carry out your objection. I object to having to see patients - wait, I haven't finished yet - when I've got laryngitis, for instance. Most of us object to the irrational guilt we're made to feel when we phone to say we won't be coming in today because we're stuck to the toilet having been poisoned by the local takeaway. A doctor friend of mine with a broken writing arm objected to being told she could still press buttons on a computer. Of course, she was expected to come to work.

Until recently, however, those with strong religious, cultural or moral beliefs have largely gone unnoticed. They've found ways to avoid finding themselves in a situation where they'd have to raise their conscientious objection. Or, although their views may not be screamed from a soapbox, 'everyone knows' that Dr X doesn't sign termination forms. They may have found sanctuary by only working with those of similar beliefs. But now, supermarkets are openly allowing their employees to pick and choose who they deal with. Want to buy alcohol? Can't serve you, I'm afraid. Want emergency contraception? Can't sell it to you, sorry. Health care has long followed the strategies of supermarkets, so what if my staff follow suit and become conscientious objectors?

Let's be perfectly frank here, no one really concerns themselves about what someone else believes. For all I care, they can argue that personality disordered members of society should be sent to therapeutic seaside resorts and not be locked up with their counterparts. They can shout about "meat being murder" till the cows come home (trampling them in the process). Unless, that is, their beliefs make more work for me. And that's the problem when you get down to the nitty-gritty of conscientious objection. None of us like being dumped on by colleagues at the best of times, even for bereavement when, to be honest, you're torn deep down you think "Why can't they have the funeral on a Saturday?" It's difficult to blame people who have firm objections because there is often self-gain to be had from these.

Given the option, I'd rather not deal with the offensive, pissed, "see me now or you'll be hearing from my lawyer" distal-ends of the GI tract. As a GP, I have little choice. And that's what concerns me about this conscientious objection stuff. Before long, I'll not only have to pick up the work of those who announce: "I'm sorry but my beliefs won't allow me to see those who wear home-knitted cardigans", but I'll also be surrounded by an increasing number of bucks that have stopped with me.

\section{J Fam Plann Reprod Health Care 2008; 34(1): 66}

Consey Enchus Surgery, Little Caring, UK Lef Twithbuck, MRCGP, General Practitioner
Ironically the problem is born of being a fair and equal opportunities employer. We could end up with a team of staff who between them conscientiously object to everything. One receptionist who won't as much as look at the young unmarried mum is going to irritate the other receptionist who has to pick up the slack. Before long, she will see the solution to this problem as deciding that, actually, she doesn't agree with multiple ear-piercing, so she can't help the patient either, and so on. That leaves me. I'll be dealing with the patient's problem, be on reception to book them in, search for their test results, and find an appointment for their relative - since no one else will. Inevitably, I'll also have to calm things down with the patient, go through an explanation of why the receptionist wouldn't so much as look at her, explain we all have our beliefs, blah, blah, blah. It's the ultimate one-stop shop me. This in turn will make me run even later, meaning more apologies, more time delays, and so on.

What about the woman wanting emergency contraception? The receptionist's belief about what the NHS should provide could be: "You bought the alcohol so you can jolly well buy the emergency contraception, young lady". The delay in her being seen may tip her over the 72-hour time limit for pills. The guidance conscientiously objects to us fitting an emergency IUD for her because we don't do enough of these. She's left with an unwanted pregnancy. She then struggles to get a termination because of the conscientious objection of others to abortion. Now her audit cycle, unlike her menstrual cycle, is neatly completed because here she is with a babe in arms listening to me feebly trying to explain how everyone is entitled to their own beliefs. To which she responds: "You're all a dead loss". I guess I asked for that and, yes, she's entitled to her beliefs too.

There is a solution and that's to have a team of staff that are conditioned to have the same beliefs. I'd have to tread carefully but psych-testing applicants would screen out those with problem-causing conscientious objections. On the other hand, I could employ lots of staff so that I'm sure to have a least one person to accommodate all eventualities. It may mean that name badges would need to become comedy T-shirts if all variables are to be included. Answering the phone would take longer: "Hello, this is the Consey Enchus Surgery, you're speaking to Mary, and I'm happy to help you with any enquiries except those involving parts of the body below the waist and above the knees. For these you'll need to speak to my colleague Norma, unless you're male, because Norma conscientiously objects to male parts since these left her having to single-handedly raise eleven children." Install a premium phone line and at least we might make extra cash from this scenario.

As a final thought, if, as a practice, we conscientiously objected to smokers, drinkers, the overweight, children, the over-60s, those with chronic diseases, and 'heartsinks', what a utopian practice we'd have. But then we'd probably object to having to be in the practice when there's no one to see. There's no pleasing some people, is there? They're so objectionable.

\section{Visit the Faculty Website at www.fsrh.org}

